\title{
ENHANCING METHANE OXIDATION IN LANDFILL COVER USING BREWERY SPENT GRAIN AS BIOCOVER
}

\author{
Siva Shangari, G.*, Agamuthu, P. \\ Institute of Biological Sciences, Faculty of Science, University of Malaya, Kuala Lumpur 50603, \\ Malaysia. *E-mail: shang.govin@gmail.com (corresponding author)
}

\begin{abstract}
Landfill gas (LFG) is a potent greenhouse gas (GHG) generated by anaerobic degradation of decomposable municipal solid wastes (MSW). LFG contains (50-60\%) of methane $\left(\mathrm{CH}_{4}\right)$ and $(40-50 \%)$ carbon dioxide $\left(\mathrm{CO}_{2}\right)$. If a landfill is neither aerated nor equipped with gas capture systems, the LFG emissions, mainly $\mathrm{CH}_{4}$, in the cover soil is best reduced by using a biocover. Biocovers normally act as a biofilter to reduce emissions by improving the biological oxidation of $\mathrm{CH}_{4}$ to $\mathrm{CO}_{2}$. In this study, the optimal ratio for a biocover using mixture of brewery spent grain (BSG) and compost made out of grass and cow manure is determined. Thereafter, column experiments were carried out to investigate the best height level of the biocover. Batch incubation experiments were conducted for screening the best ratio of BSG to compost. A mixing ratio from $10 \%$ to $100 \%$ BSG to compost with $10 \%$ increment was tested. The best ratio of BSG to compost was 7:3. This ratio was later tested with different parameters such as $\mathrm{pH}$, moisture content and temperature. Overall, the optimum biocover performance was at $\mathrm{pH} 6$, moisture content of $66 \%(\mathrm{v} / \mathrm{v})$ and temperature of $40^{\circ} \mathrm{C}$. The column experiments showed that $100 \% \mathrm{CH}_{4}$ oxidation occurred fastest at the height of $50 \mathrm{~cm}$.
\end{abstract}

(Keywords: Greenhouse gas, methane oxidation, biocover, brewery spent grain, compost)

\section{INTRODUCTION}

Climate change mitigation efforts to date have been mainly concerned with reducing emissions of $\mathrm{CO}_{2}$. However, recent research has drawn interest to the importance of $\mathrm{CH}_{4}$, the second most abundant GHG after $\mathrm{CO}_{2}$. $\mathrm{CH}_{4}$ is 25 times more potent than $\mathrm{CO}_{2}$ in trapping heat in the atmosphere [1]. In a report by USEPA [2], the five main sources of $\mathrm{CH}_{4}$ are identified as agriculture, coal mines, landfills, oil and natural gas systems and waste water. Globally landfills account for $12 \%$ of $\mathrm{CH}_{4}$ emission [2] while in Malaysia it is about $47 \%$ of the total $\mathrm{CH}_{4}$ emission [3]. Emissions of $\mathrm{CH}_{4}$ from landfills are due to anaerobic decomposition of organic material stemming from MSW.

In Malaysia, 30,000 tonnes of MSW are disposed of in landfills and dumpsites each day [4]. Over the past 10 years, the generation of MSW has increased more than $91 \%$ with the urban population being the main waste generators and it accounts for an average of 1.3$7.5 \mathrm{~L} / \mathrm{kg} /$ year of $\mathrm{CH}_{4}$ released into the atmosphere [5]. Since the landfills are small and do not have extensive gas collection system, an alternative method is used to mitigate the $\mathrm{CH}_{4}$ emission. One such method is by introducing a biocover to the cover soil at landfills which possess the capacity of $\mathrm{CH}_{4}$ oxidation to $\mathrm{CO}_{2}$.

The objective of this study is to design a suitable biocover material using organic wastes that are capable of oxidizing $\mathrm{CH}_{4}$ into $\mathrm{CO}_{2}$. Also studied is the thickness level of the biocover material that is needed for maximum $\mathrm{CH}_{4}$ oxidation.

\section{MATERIAL AND METHODS}

\section{Compost}

Compost pile of grass clippings and cow manure with a ratio of 75 to 25 was made following the heap method [6],[7]. The ratio was chosen to optimize conditions within the pile in terms of nutrition, oxygen, moisture content, $\mathrm{pH}$ and temperature levels so that an ideal rate of microbial activity is achieved. Daily mixing of the compost pile was done to maintain the aeration and optimum composting for 10 days and thereafter the mixing was done on alternate days. The moisture content was maintained between 40 to $70 \%$ throughout the composting period by adding sufficient water when required. The ASTM Standard D2216 (2005) was used to determine the moisture content of the compost by oven drying $5 \mathrm{~g}$ of compost overnight at 
$105^{\circ} \mathrm{C}$ and expressed as the mass ratio of water content to wet compost. The $\mathrm{pH}$ was measured using the indoor Metler Toledo $\mathrm{pH}$ meter. Daily temperature readings were taken using a laboratory thermometer until a stable temperature profile was recorded. The compost pile took 2 to 3 days to increase beyond mesophilic $\left(10-40^{\circ} \mathrm{C}\right)$ temperatures and reach the thermophilic $\left(41-70^{\circ} \mathrm{C}\right)$ stage of composting. Later it decreased to ambient level.

\section{Brewery Spent Grain}

Brewery spent grain (BSG) is a by-product of the brewery industry, representing about $85 \%$ of the total by-product generated [8]. It is an organic waste from barley and other cereal malts used in the production of beer [9]. In Malaysia, BSG is available throughout the year and its main application is for animal feed because of the high protein and fibre content $(20-70 \%$ respectively by dry weight) [8]. However, it is under-utilized with approximately $15 \%$ sold for feedstock while the balance discarded to landfills [10]. In this study, fresh BSG was obtained from Carlsberg Brewery Malaysia Berhad and used immediately. The $\mathrm{pH}$, temperature and moisture content were determined using the same methods used for compost.

\section{Batch incubation experiments}

Batch incubation experiments were carried out using Wheaton bottles. Mixture of BSG and compost ranging from 10 to $100 \%$ ratio of $\mathrm{BSG}$ to compost with a $10 \%$ increase was prepared in $150 \mathrm{ml}$ bottles in triplicates. Each bottle with $20 \mathrm{~g}$ of substrate (compost and BSG) was sealed with a septa and aluminium seal to ensure air tight. Then $18 \mathrm{ml}$ of air was withdrawn from the headspace of each Wheaton bottle using an airtight syringe and replaced with $6 \mathrm{ml}$ of $\mathrm{CH}_{4}$ gas $\left(99.9 \%\right.$ purity) and $12 \mathrm{ml}$ of $\mathrm{O}_{2}$ gas $(99.98 \%$ purity). This amount provided a mixing ratio of approximately $4 \%$ of $\mathrm{CH}_{4}(\mathrm{v} / \mathrm{v})$ and $8 \% \mathrm{O}_{2}(\mathrm{v} / \mathrm{v})$ required for substrate saturation and determination of maximum $\mathrm{CH}_{4}$ oxidation rate [11]. $\mathrm{O}_{2}$ gas in the headspace maintains an aerobic condition within the bottles during the experiments. The concentrations of $\mathrm{CH}_{4}, \mathrm{O}_{2}$ and $\mathrm{CO}_{2}$ in the headspace were measured daily using the Shimadzu 8A Gas Chromatography (GC) equipment to quantify the $\mathrm{CH}_{4}$ oxidation rate for the different ratios. The procedures were repeated for other tested ratio under different factor of $\mathrm{pH}$, moisture content and temperature.

\section{The influence of moisture content}

The influence of moisture content on $\mathrm{CH}_{4}$ oxidation was tested using different percentages of moisture content. The original moisture content of the mixture was about $66 \%$ and it was used as a control setup. Moisture content is lowered by oven drying the mixture while it is increased by adding deionised water to the mixture. Moisture content of $50 \%$ to $80 \%$ was tested using triplicate bottles.

\section{The influence of $\mathbf{p H}$}

The influence of $\mathrm{pH}$ on $\mathrm{CH}_{4}$ oxidation was tested by modifying the $\mathrm{pH}$ of mixture ranging from $\mathrm{pH} 4$ to $\mathrm{pH} 8$. Sulphuric acid was added to lower the $\mathrm{pH}$ level while nitric acid was used to increase the $\mathrm{pH}$ level. The original $\mathrm{pH} 6$ of the mixture was used as the control. Each $\mathrm{pH}$ was done in triplicate and headspace gas was analysed using GC. The analysis was carried out until the $\mathrm{CH}_{4}$ concentration becomes zero or reaches a plateau.

\section{The influence of temperature}

The influence of temperature on $\mathrm{CH}_{4}$ oxidation was tested between $25^{\circ} \mathrm{C}$ to $55^{\circ} \mathrm{C}$ with $5^{\circ} \mathrm{C}$ increase. Triplicates samples were incubated in different temperature setting and analysed until the $\mathrm{CH}_{4}$ concentration becomes zero or reaches a plateau. The original temperature $30^{\circ} \mathrm{C}$ was used as a controlled experiment.

\section{Column experiments}

The column experiments represented an advanced step for evaluating the $\mathrm{CH}_{4}$ oxidation of biocover material of certain thickness or height. The best BSG to compost ratio and with the optimum parameters from the batch incubation experiments were chosen for the column experiment. The columns were prepared in duplicates and the experiment was repeated twice. Columns of one- $m$ height were fabricated using $10 \mathrm{~mm}$ thick PVC with an internal diameter of $0.15 \mathrm{~m}$. Sampling ports at $0.1 \mathrm{~m}$ interval enable gas sampling at different heights. The biocover material i.e. the best BSG to compost ratio was placed inside the columns and the top of the column was sealed with a $5 \mathrm{~mm}$ thick plexiglass to ensure air-tight. Similar to the batch incubation experiment approximately $4 \%$ of $\mathrm{CH}_{4}$ $(\mathrm{v} / \mathrm{v})$ and $8 \% \mathrm{O}_{2}(\mathrm{v} / \mathrm{v})$ was introduced into the column using a Dwyer Rate-Master flow meter. 
Later, the gas samples at each port were analysed using GC.

\section{RESULTS AND DISCUSSION}

\section{Material properties}

Table 1: The physiochemical properties of the compost and fresh BSG used for batch incubation and column experiments

\begin{tabular}{llll}
\multicolumn{1}{c}{ Test Parameter } & \multicolumn{1}{c}{ Test Method } & \multicolumn{1}{c}{ Compost } & $\begin{array}{c}\text { Fresh Brewery Spent } \\
\text { Grain }\end{array}$ \\
\hline Moisture content (\%) & ASTM 2004 & $62.17 \pm 0.14 \%(\mathrm{v} / \mathrm{v})$ & $70.58 \pm 0.14 \%(\mathrm{v} / \mathrm{v})$ \\
\hline $\mathrm{pH}$ & ASTM 2004 & $6.33 \pm 0.12$ & $4.41 \pm 0.12$ \\
\hline Organic matter (\%) & ASTM 830-97 & $63.6 \%$ & $73.6 \%$ \\
\hline Total carbon (\%) & ASTM 777-87 (96) & $20.3 \%$ & $40.1 \%$ \\
\hline Total nitrogen (\%) & ASTM E778-87 & $1.20 \%$ & $1.07 \%$ \\
\hline Carbon: Nitrogen ratio & USEPA 3050B & $17: 1$ & $38: 1$ \\
\hline
\end{tabular}

The moisture content, organic matter, $\mathrm{pH}$ and $\mathrm{C}$ and $\mathrm{N}$ ratio are important parameters for materials used. Both materials used in this study have moisture content above $60 \%$ which has the ability to retain water to sustain the microbial population for $\mathrm{CH}_{4}$ oxidation [12]. Compost with neutral to slightly acidic $\mathrm{pH}$ optimized the $\mathrm{CH}_{4}$ oxidation [13] but the acidic $\mathrm{pH}$ of raw BSG is not favourable. Nutrient rich soil increases the $\mathrm{CH}_{4}$ oxidation rate. Carbon is used a source of energy for growth of microbes while nitrogen is used for synthesis of cellular material, amino acids and proteins [14]. Therefore, the organic matter and $\mathrm{C}: \mathrm{N}$ ratio enhanced $\mathrm{CH}_{4}$ oxidation and both materials used in this experiment are in the optimal range.
The physiochemical properties of compost and BSG are given in Table 1. All material properties were measured by following the methods prescribed in ASTM and USEPA standards.

\section{BSG to compost ratio}

Figure 1 shows the $\mathrm{CH}_{4}$ oxidation among the different ratios of BSG to compost from the batch incubator experiment. The BSG to compost ratio of 7:3 had the highest percentage of $\mathrm{CH}_{4}$ oxidation of $64.5 \%$ while $100 \%$ had the lowest $\mathrm{CH}_{4}$ oxidation (5.7\%). The poor performance of the $100 \%$ BSG was attributed to inactive microbes in BSG which hindered $\mathrm{CH}_{4}$ oxidation. The compost added to BSG provides the mixtures with either microbes or nutrients for the microbes in BSG for $\mathrm{CH}_{4}$ oxidation. This is an indicative that methanotrophic activity is present and could be accelerated with the addition of compost but only at suitable amount. This is evident in the ratios of 1:9 and 9:1 BSG to compost. Thus, the best ratio was chosen for further investigation with different parameter such as $\mathrm{pH}$, moisture content and temperature. 


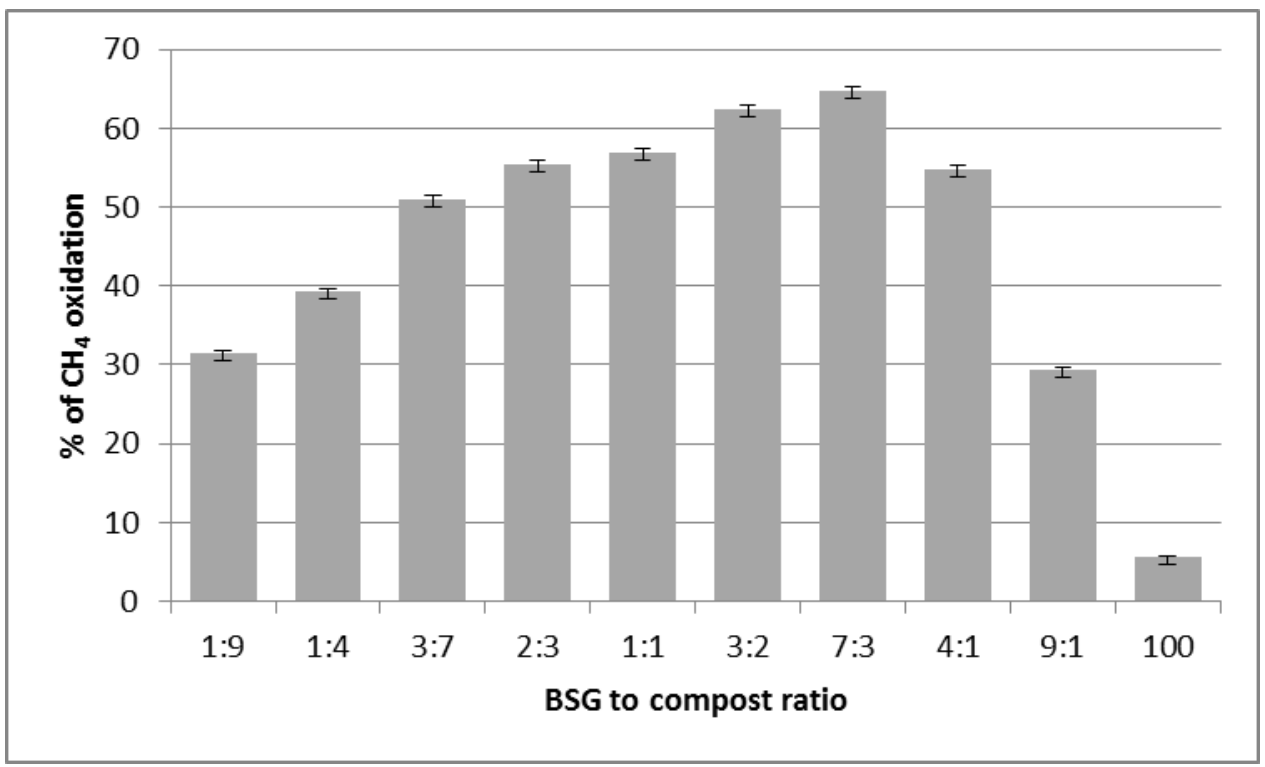

Figure 1: Percentage of $\mathrm{CH}_{4}$ oxidation at different $\mathrm{BSG}$ to compost ratio.

Moisture content, $\mathrm{pH}$ and temperature response experiments

Figure 2 shows the influence of moisture content, $\mathrm{pH}$ and temperature on $\mathrm{CH}_{4}$ oxidation by the 7:3 BSG to compost ratio. The shaded bar in each chart represents the control experiment. In Figure 2(a), the control showed the highest percentage of $\mathrm{CH}_{4}$ oxidation (more than 60\%) indicating that the suitable moisture content for optimum $\mathrm{CH}_{4}$ oxidation for this ratio. At $80 \%$ moisture content, the percentage $\mathrm{CH}_{4}$ of oxidation is the lowest $(<10 \%)$. This suggested that very high moisture $(>70 \%)$ does not sustain microbial population for $\mathrm{CH}_{4}$ oxidation. Previous

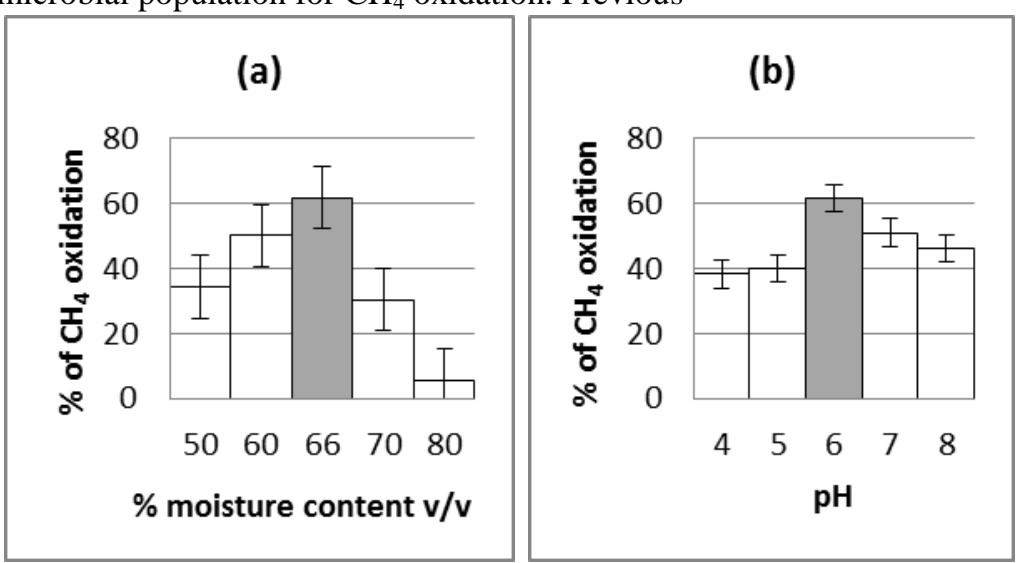

studies have also shown that extreme conditions related to moisture content can limit $\mathrm{O}_{2}$ diffusion [15] or cause physiological stress to the microbes [16],[17]. In landfill condition the biocovers tend to oxidize more $\mathrm{CH}_{4}$ than the laboratory scale experiment. But high moisture content has a potent risk of producing $\mathrm{CH}_{4}$ [18] due to the high methanogenesis activity.

In Figure 2(b) the optimum $\mathrm{pH}$ was evaluated. Very acidic $\mathrm{pH}$ has a low percentage (below $40 \%$ ) of $\mathrm{CH}_{4}$ oxidation while neutral to slightly alkaline $\mathrm{pH}$ gave higherCH $\mathrm{H}_{4}$ oxidation (40\%). Studies by

Figure 2: Influence of (a) moisture content, (b) $\mathrm{pH}$ and (c) temperature on $\mathrm{CH}_{4}$ oxidation

previous researches show that optimal $\mathrm{pH}$ ranges from $\mathrm{pH} 6.6$ to 8.1 [19] and again it depends on the methanotrophs present in the material used. Figure 2(c), shows that the optimum temperature ranged from 30 to $45^{\circ} \mathrm{C}$ with more than $60 \%$ of $\mathrm{CH}_{4}$ oxidation. Similar studies by Perez, [19] depict that $\mathrm{CH}_{4}$ oxidation occurs at range of temperatures and certain temperatures 
favour certain type of methanotrophs. In this study, the highest percentage of $\mathrm{CH}_{4}$ oxidation was obtained at $40^{\circ} \mathrm{C}$.

\section{Column Experiment}

The best BSG to compost ratio, optimum moisture content, $\mathrm{pH}$ and temperature from the batch incubation experiments were chosen for the column experiments. While the optimum moisture content and $\mathrm{pH}$ were of the original material used, only the temperature was adjusted to the optimum level of $40^{\circ} \mathrm{C}$ for the column experiments. Columns were put in incubators with $40^{\circ} \mathrm{C}$ throughout the study period. $\mathrm{CH}_{4}$ and $\mathrm{O}_{2}$ were introduced through the bottom valve of the columns to simulate the condition in landfills where methane is released below the biocover material [20].

Figure 3 presents the results from the column experiments on $\mathrm{CH}_{4}$ oxidation efficiency at different biocover thickness level. The error bars indicates the standard deviations from the experiments conducted. Day 0 represents the day $\mathrm{CH}_{4}$ gas is introduced to the column. Initial analysis with GC shows that the $\mathrm{CH}_{4}$ concentration is highest at $10 \mathrm{~cm}$ and fluctuates at the other height levels. This could be because the $\mathrm{CH}_{4}$ gas has not fully diffused throughout the column.

In Day 1, a more homogenous concentration of $\mathrm{CH}_{4}$ is obtained after much diffusion of the gas within the column. Between Day 2 to Day 4 (histograms not shown here), $\mathrm{CH}_{4}$ oxidation was observed at all level of height. On Day 5, as shown in Figure 3, $\mathrm{CH}_{4}$ concentration at $50 \mathrm{~cm}$ decreased to zero indicating $100 \% \quad \mathrm{CH}_{4}$ oxidation. While on Day 6 (also histograms not shown here) $100 \% \mathrm{CH}_{4}$ oxidation was observed at all level of height. This concludes that within 5 days this biocover material (mixture of BSG and compost) is able to fully oxidize $\mathrm{CH}_{4}$ at $50 \mathrm{~cm}$ height.

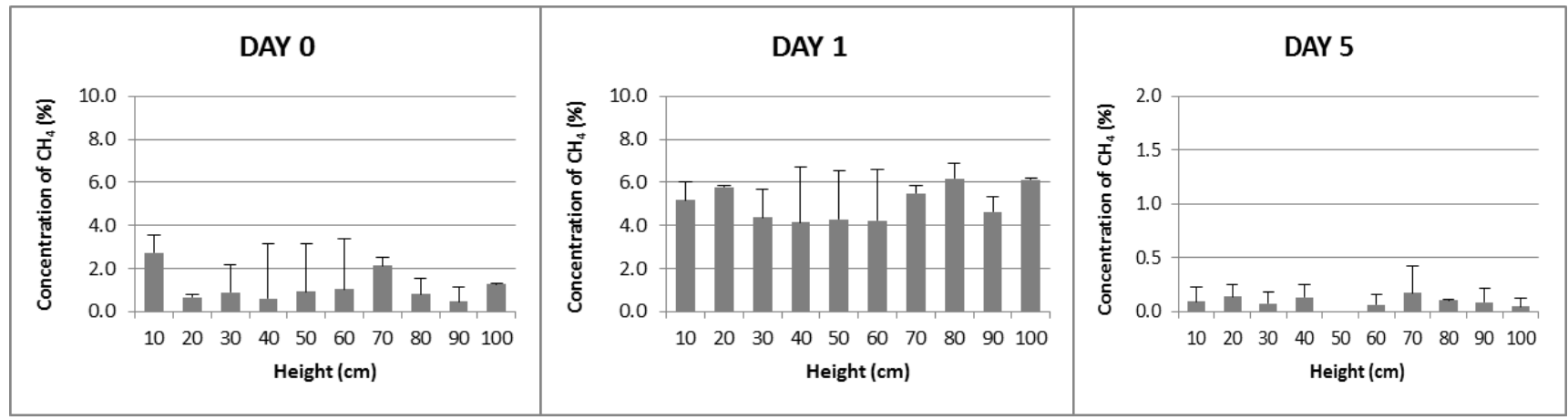

Figure 3: $\mathrm{CH}_{4}$ concentration in percentage for Day 0, Day 1 and Day 5 of column experiment.

In batch incubation experiments the maximum $\mathrm{CH}_{4}$ oxidation was about $64.48 \%$ in 14 days while in column experiments $100 \% \quad \mathrm{CH}_{4}$ oxidation was achieved between 5 to 6 days. A reason suggested for this difference, is the amount of material used for the batch incubation experiment is insufficient $(20 \mathrm{~g})$ compared to the total material in the column which is about $10 \mathrm{~kg}$ to $13 \mathrm{~kg}$. Therefore, the amount of material in batch incubation experiments has attained a saturation level in oxidizing $\mathrm{CH}_{4}$.

\section{CONCLUSION}

The optimal ratio of $\mathrm{BSG}$ to compost as the biocover material is 7:3 with optimum parameters were moisture content of $66 \%, \mathrm{pH}$ of 6 and temperature of $40^{\circ} \mathrm{C}$. The column experiments showed complete $100 \% \quad \mathrm{CH}_{4}$ oxidation on day 5 at $50 \mathrm{~cm}$ height and day 6 for the others. The results also show that both batch incubation experiments and column experiments enhanced $\mathrm{CH}_{4}$ oxidation. However, the batch incubation experiments does not show $100 \%$ $\mathrm{CH}_{4}$ oxidation compared to that of column experiments.

\section{ACKNOWLEDGEMENT}

The authors thank all individuals directly or indirectly involved in this project for their academic and technical support. We thank the University of Malaya's RG143/11SUS and PPP (PV009/2012A) for providing the necessary funding for realizing the project. We also thank Carlsberg Brewery (M) Berhad for their contribution. 


\section{REFERENCES}

1. IPCC, 2007, Intergovernmental Panel for Climate Change, Climate change 2001: The Scientific Basis, Cambridge University Press, Cambridge, UK

2. USEPA, 2006, Global Anthropogenic Emissions of Non- $\mathrm{CO}_{2}$ Greenhouse Gases : $1990 \quad$ - 2020, US Environmental Protection Agency, Washington DC, (EPA Report 430-R06-003)

3. NC2-Malaysia, 2010, Malaysia's Second National Communication (NC2) to the United Nations Framework Convention on Climate Change (UNFCCC) Report. Ministry of Natural Resources and Environment Malaysia Publications. ISBN 987-983-44294-9-2.

4. Agamuthu P. \& Fauziah SH. Challenges and issues in moving towards sustainable landfilling in a transitory country - Malaysia. Waste Management and Research 2011; 29(1); p. 13-19

5. Agamuthu P., Fauziah, S.H., \& Kahlil Khidzir. Evolution of Solid Waste Management In Malaysia : Impact and Implications of the Solid Waste Bill 2007, Journal of Material Cycles and Waste Management : Special Issue for the $3^{\text {rd }}$ Expert Meeting On Solid Waste Management in Asia and Pasific Islands, 2009; 11; p.1611-8277

6. Jayanthi B. \& Agamuthu P. Enhancement of methane oxidation with effective methanotrophic mixed cultures. Malaysian Journal of Science 2011; 30 (1); p. 28-35

7. Boon Tien L. \& Agamuthu P. Comparison of methane oxidation potential between compost and black soil at Jeram Landfill. Malaysian Journal of Science 2011; 30 (2); p. 92 98

8. Mussatto S.I, Dragone G. \& Roberto I.C. Brewers' spent grain: generation, characteristics and potential applications. Journal of Cereal Science 2006; 43; p. $1-14$
9. Thomas, K. R. \& Rahman, P. K. S. M. Brewery wastes. Strategies for sustainability. A review. Aspects of Applied Biology 2006; 80; p.147-153

10. Khidzir K.M., Noorlidah Abdullah \& Agamuthu P. Brewery spent grain: Chemical characteristics and utilization as an enzyme substrate. Malaysian Journal of Science 2010; 29 (1); p. 4151

11. Perdikea K., Mehrotra A. K. \& Hettiaratchi J.P.A. Study of thin biocovers (TBC) for oxidizing uncaptured methane emissions in biocover landfills. Waste Management 2008; 28; p 1364-1374

12. Hilger H. \& Humer M. Biotic landfill covers trearments for mitigating methane emissions. Environmental Monitoring and Assessment 2003; 84; p. $71-84$.

13. Moldes A., Cendon Y. \& Barral M. T. Evaluation of municipal solid waste compost as a plant growing media component by applying mixture design. Bioresource Technology 2007; 98; p. 3069-3075.

14. Graves E. R \& Hattemer G. M. Environmental Engineering : National Engineering Handbook, Chapter 2 : Composting. US Department of Agriculture 2000, p 2-8

15. Boeckx, P., \& Van Cleemput, O. V. Methane oxidation in a neutral landfill cover soil: influence of moisture content, temperature, and nitrogenturnover. Journal of Environmental Quality 1996; 25 (1); p. 178-183.

16. Whalen, S. C., Reeburgh, W. S., \& Sandbeck, K. A. Rapid methane oxidation in a landfill cover. Applied Environmental Microbiology 1990; 56; p. 3405-3411.

17. Dobbie, K. E., \& Smith, K. A. Comparison of $\mathrm{CH} 4$ oxidation rates in woodland arable and set aside soils. Soil 
Biology and Biochemistry 1996; 28 (10-11); p.1357-1365.

18. Barlaz M.A., Green R.B., Chanton J.P., Goldsmith C.D. \& Hater G.R. Biologically active cover for mitigation of landfill gas emission. Environmental Science and Technology 2004; 38; p. 4891 - 4899 .

19. Perez, O.D.H. 2009. Thin biocovers for methane emission mitigation. $\mathrm{PhD}$ Thesis, University of Calgary, Calgary, Alberta, Canada.

20. Navarani V. 2009. Bioremediation of landfill gas under laboratory conditions. M. Tech Thesis, Universiti Malaya, Kuala Lumpur, Malaysia. 